\section{La rebelión de los colgados}

Traven, Bruno

(1952)

General de Ediciones, México, [Trad. En español por López Mateos, Esperanza (2008), La Rebelión de los Colgados, Ed. Selector, México

\section{Liliana Lizbeth García Razo}

deelishis_liliz@hotmail.com

Esta obra, escrita en el año de 1952 por el político anarquista alemán Bruno Traven, se inspira en la precaria situación de los mexicanos indígenas a principios del siglo XX. Narra la historia de un indio chamula originario de Chiapas llamado Cándido que, a base de manipulaciones y engaños es enviado a las monterías. Las monterías eran lugares alejados donde se cortaba caoba de los bosques y así venderla para producir diversos materiales de madera.

Cándido, tras la muerte de su esposa se fue con sus dos hijos y con su hermana a la montería. Al llegar a dicho lugar, se dio cuenta que los trataban como esclavos: les pagaban muy poco dinero al día y los obligaban a trabajar aproximadamente 16 horas diarias cortando cuatro toneladas de caoba por persona. Además les daban muy poca comida que solo consistía en arroz, frijoles, tortillas y café. Cuando los peones no juntaban la cantidad de toneladas requerida al día los castigaban colgándolos de los árboles toda una noche sin importarles si les daba hipotermia o si los atacaban los animales salvajes. También eran azotados despiadadamente por los dueños y capataces de las monterías. Tras no poder escapar y sufrir todas estas injusticias, un maestro que también era peón alienta a los demás a rebelarse ante los capataces para poder al fin obtener su libertad. Planean una rebelión y matan a los capataces y a los dueños de las monterías. Se roban las armas y se van de ese terrible lugar.

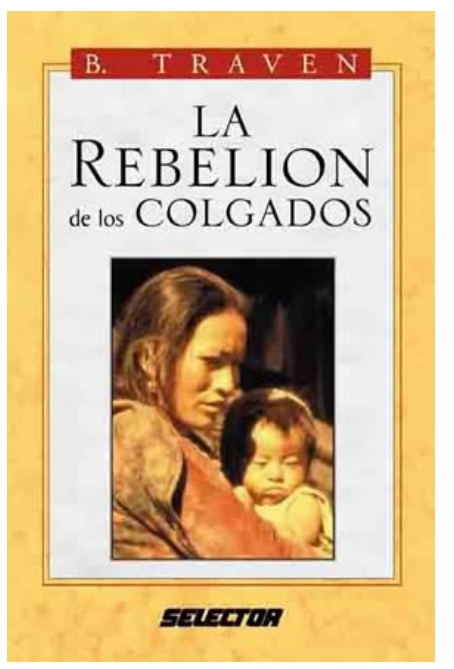

El libro no tiene conclusión ni final pero esto es útil ya que el lector le da su propio final a la historia.

Para mí este libro es muy realista ya que, a pesar de que se remonta a principios del siglo pasado, las situaciones de injusticia y discriminación social hacia los indígenas siguen latentes. Describe muy detallada y explícitamente los abusos y sometimientos sufridos por estos indios. Hoy en día existen condiciones de pobreza muy notorias en nuestro país y con ello, cuestiones de lesión y dolo por parte de los gobernantes y de las instituciones gubernamentales. Me deja una reflexión muy profunda porque alguien debe hacer algo para cambiar la situación de nuestro país.

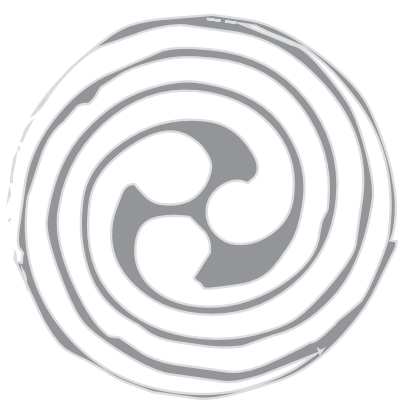

